\title{
Jurisdiction in criminal matters in the EU: negative and positive conflicts, and beyond ${ }^{1}$
}

\section{Introduction}

1. The prevention of conflicts of jurisdiction was brought into the Treaty on the European Union by the Treaty of Amsterdam ${ }^{2}$ (TEU-A) as a means of furthering "common action on judicial cooperation in criminal matters", ${ }^{3}$ which was to be "developed" in order to attain the objective of providing citizens "with a high level of safety within an area of freedom, security and justice". ${ }^{4}$

However, for over 10 years, and despite some references in subsequent European instruments of a general nature, the prevention of conflicts of jurisdiction seems to have been almost ignored by policy makers. Arguably, the duty of the European Union (EU) to prevent positive conflicts was plainly violated by framework decisions that have multiplied, with no apparent need, mandatory and optional principles of jurisdiction (or, more accurately, rules of applicability), ${ }^{5}$ to be adopted by Member States in their criminal law systems. In those cases, the EU created the conditions for positive conflicts of jurisdiction instead of preventing them, but no great importance was given to the fact that EU organs were not paying due respect to the Treaty. ${ }^{6}$

2. According to article 82 (1) (b) of the Treaty on the Functioning of the European Union (TFEU), "the European Parliament and the Council, acting in accordance with the ordinary legislative procedure, shall adopt measures to prevent and settle conflicts

1 This article is based on the presentation given at the Conference Criminal Justice in Europe: Challenges, Principles and Perspectives (University of Luxembourg - October 2010), which was part of the Panel European Justice as a control of mutual cooperation of EU Member States: the principle of "ne bis in idem" and conflicts of competences as challenges. The author wishes to thank Prof. André Klip and Mrs. Anne-Sophie Massa for their valvable comments on the manuscript.

2 The following abbreviations will be used for the Treaty on the European Union: TEU-A (version introduced by the Treaty of Amsterdam); TEU-N (version introduced by the Treaty of Nice); and TEU-L (version introduced by the Treaty of Lisbon).

3 Article 31 (d) TEU-A: "Common action on judicial cooperation in criminal matters shall include:(...)(d) preventing conflicts of jurisdiction between Member States".

4 Article 29 TEU-A: “( ...) the Union's objective shall be to provide citizens with a high level of safety within an area of freedom, security and justice by developing common action among the Member States in the fields of police and judicial cooperation in criminal matters (...)".

5 Pedro Caeiro, Fundamento, Conteúdo e Limites da Jurisdição Penal do Estado. O Caso Português, Wolters Kluwer / Coimbra Editora, 2010, p. $215 \mathrm{ff}$.

6 See Jorge de Figueiredo Dias / Pedro Caeiro, “A Lei de Combate ao Terrorismo (Lei n ${ }^{\circ}$ 52/2003, de 22 de Agosto). Sobre a transposição, para o direito português, da Decisão-quadro do Conselho, de 13 de Junho de 2002, relativa à luta contra o terrorismo", Revista de Legislação e Jurisprudência 135 (2005), $\mathrm{n}^{\circ}$ 3935, p. 75. 
of jurisdiction between Member States". ${ }^{7}$ Thus, the Treaty of Lisbon added the settlement of conflicts of jurisdiction to the competences of the EU and made clear that the European Parliament and the Council are bound to adopt legislative measures in order to achieve those goals.

3. Most authors and official documents link the prevention and settlement of conflicts of jurisdiction together with ne bis in idem and the title of this panel suggests the same.

There are good reasons for addressing both issues in a comprehensive manner. Ne bis in idem supposes a positive conflict of jurisdiction and, in a way, it might be seen as an abstract mechanism of settling (positive) conflicts of jurisdiction, by establishing a rule that reads: "whenever there is a positive conflict of jurisdiction in the EU, the decision that finally disposes of the case in one State prevents all other interested States from exerting their jurisdiction". ${ }^{8}$ Moreover, the very existence of this rule seems to attract further reflection on the need for a binding mechanism that allocates jurisdiction according to previously agreed upon criteria, so that the competence to dispose of the case with the exclusion of all other jurisdictions is not a matter of chance. ${ }^{9}$

Nevertheless, the sudden momentum gained by ne bis in idem and the ever increasing elaboration of the rule might have "absorbed" the issue of conflicts of jurisdiction, narrowing the perspective. At the moment, it would seem that only positive conflicts of jurisdiction are at stake, ${ }^{10}$ and only to the extent that is necessary to circumvent some unwanted consequences of ne bis in idem.

In this paper, it is submitted that article $82^{\circ}$ (1) (b) TFEU should be given a much broader scope, consistent with building up an area of freedom and justice in the context of European legal pluralism (=partial integration of substantive criminal law). To put the argument forward, it is necessary to restate some concepts.

\section{Jurisdiction in criminal matters}

1. In its subjective sense, jurisdiction in criminal matters is the legitimate power under international law to decide which conduct shall and shall not constitute a criminal of-

7 Concurrent (prescriptive) jurisdiction between the EU and Member States is organised both through the rules laid down in the Treaties (e. g., the States' duty to transpose European directives into domestic law) and in national Constitutions (e. g., the constitutional reception of European integration or, hypothetically, the exemption of European criminal law from the subjective dimension of the principle of legality - nullum crimen sine lege parlamentaria); on the construction of those "points of balance", see Pedro Caeiro (n. 5), p. $116 \mathrm{ff} ., 526 \mathrm{ff}$. and passim.

8 But see infra, III, 3.4.

9 See André Klip, European Criminal Law, Intersentia, 2008, p. 423 f.

10 See Kai Ambos, Internationales Strafrecht. Strafanwendungsrecht. Völkerstrafrecht. Europäisches Strafrecht, 2nd Ed., Beck, 2008, § 12, mn. 8 and 20. 
fence and to decide whether a concrete act violates a penal norm, with a view to punish the perpetrator. ${ }^{11}$

For that purpose, it is necessary to adopt norms that define criminal conduct (primary norms) and norms that draw the sphere of applicability of the former (secondary norms, or rules of applicability). These functions fit into what is commonly known as prescriptive jurisdiction. Finally, the jurisdiction holder must also define the ambit of the competence of its courts, that is to say, the ambit of its adjudicative jurisdiction. ${ }^{12}$

a) Primary norms entail the content of the prohibition (what is forbidden), while secondary norms draw the reach, or scope, of the prohibition (the circle of addressees to whom primary norms apply, or jurisdiction in an objective sense [Gebiet]), by requiring a relevant connection of the conduct with that legal order. This connection can blend factual and normative elements (e. g., territoriality, nationality) or rather have a purely normative nature (e.g., an international obligation binding a State to exert extraterritorial jurisdiction over certain types of crimes).

The conjunction of both sets of norms will give us a basic picture of the contents and reach of a given criminal law system.

b) There is a general coincidence between the ambit of adjudicative jurisdiction and the scope of primary norms that belong to the same juridical system. Nevertheless, such coincidence is not perfect: it can happen that a given act is described by the primary and secondary norms of the legal order at hand, but cannot be prosecuted and tried because adjudicative jurisdiction is barred (e. g., by virtue of ne bis in idem, ${ }^{13}$ or of an immunity ratione personae granted by international law); ${ }^{14}$ it can also happen that a State lets his authorities prosecute and try conduct that does not fall under the scope of its primary norms (e. g., by providing for direct application of international criminal law, ${ }^{15}$ accepting the transfer of penal proceedings, or exerting surrogate jurisdiction). ${ }^{16}$

Therefore, adjudicative jurisdiction in criminal matters might be defined as the legitimate power under international law to ascertain whether a given conduct violates a (domestic, international or foreign) norm that the courts of a given judicial system are

11 The term "jurisdiction" seems more adequate than "punitive power" (Strafgewalt), since it bears an inherent demand for legitimacy (iuris): as Judge Antonio Cassese has put it in the Tadic appeal, only he who has a legitimate power can state the law (ICTY, Decision on the Defence Motion for Interlocutory Appeal on Jurisdiction, Prosecutor v. Dusko Tadic, Case NN IT-94-1-AR72, A. Ch., 2-10-1995, para. 10, in André Klip / Göran Sluiter (eds.), Annotated Leading Cases of International Criminal Tribunals. I. The International Criminal Tribunal for the former Yugoslavia 1993-1998, 1999, p. 38), and this reasoning applies both to prescriptive and adjudicative jurisdiction (see also Joseph Beale, "The jurisdiction of a sovereign State", HLR 36 (1922-23), p. 243).

12 Actually, only the first two sets of norms participate in the definition of the duties prescribed by criminal law: establishing the ambit of competence of the courts is part of the legislative function but does not contend with the abstract definition of prohibited behaviour.

13 See infra, III, 3.4.

14 See, e. g., Antonio Cassese, "When may senior state officials be tried for international crimes? Some comments on the Congo v. Belgium case", EJIL 13-4 (2002), p. $862 \mathrm{ff}$., with further references.

15 See article $29^{\circ}, \mathrm{n}^{\circ} 2$, together with article $8^{\circ}, \mathrm{n}^{\circ} 1$ and 2 , of the Portuguese Constitution.

16 On the possible asynchronies between the reach of a given criminal law system and the jurisdiction of its courts, in more detail, Pedro Caeiro (n. 5), p. $331 \mathrm{ff}$. 
bound to apply. Furthermore, adjudicative jurisdiction includes the power (or, more accurately, the duty) to check its own existence, in the sense that the appropriate organs should make sure that, in the particular case at stake, no bars to adjudicative jurisdiction apply.

2. In the Treaty of Amsterdam, the European Union was endowed with the power to adopt legislative measures (framework decisions) in criminal matters. Whether or not such power amounted to an autonomous (prescriptive) jurisdiction in criminal matters was an issue open to debate, since framework decisions had to be approved by unanimous vote of the Member States sitting in Council. However, after the extension of the majority rule to legislative acts on matters formerly included in the third pillar, ${ }^{17}$ it is now indisputable that the EU has a true, albeit limited (ratione modi ${ }^{18}$ and ratione materiae), ${ }^{19}$ (prescriptive) jurisdiction in criminal matters.

\section{Negative and positive conflicts of jurisdiction in criminal matters}

\section{Definition}

1.1. The expression "conflicts of jurisdiction in criminal matters" does not have a mere factual content. It does not purport to describe situations where a plurality of holders (States or other entities) lack or bear jurisdiction over a case. Rather, it means that, from a certain point of view, some State (or entity) should have or exert jurisdiction over a case, when in fact none has or does (negative conflict), or, conversely, that the concurrent holders should not adjudicate the case as if there were no claims from other jurisdictions (positive conflict).

17 Articles 83 (1), 238 (1) and 294 TFEU.

18 As far as the approximation of primary norms (the "definition of criminal offences and sanctions") is concerned, the EU cannot pass legislation that immediately imposes duties on individuals (regulations with direct applicability), because article 83 limits EU competence to the enactment of directives. Arguably, this restriction applies also to the prevention of negative conflicts of jurisdiction (see infra, 2.).

A second limitation ratione modi lies in the circumstance that, while defining criminal offences and sanctions, the EU can only establish "minimum rules", i.e., minimum thresholds of criminalisation and punishment (criticising this exotic, one-limbed jurisdiction, Pedro Caeiro (n. 5), p. 499, 566 f.). However, the "minimum rules" programme applies only - by definition - to the prevention and settlement of negative conflicts of jurisdiction (see infra, 2.).

19 The approximation of primary norms is also limited by some material boundaries, set in article 83: the listed "areas of crime" (1) and areas that have been subject to "harmonisation measures" (2). The Treaty has thus embodied the Annexkompetenz theory followed by the Court of Justice in the notorious decision Case 176/03, Commission of the European Communities v. Council of the European Union, 13.09.2005, ECR (2005) I-7879 (which was itself inspired by article III-271(2) of the Constitutional Treaty, but, it is submitted, with no sound basis in the Treaties then in force), and it is now clear that all EU competences for the approximation of primary criminal law are to be found in article 83 , not elsewhere from where the Commission (and, for that matter, the Court of Justice) might wish to infer them. Arguably, this material restriction applies also to the prevention of negative conflicts of jurisdiction (see infra, 2.). 
Thus, asserting that there is a conflict of jurisdiction has a normative value: according to certain criteria, someone should act, or should refrain from acting, or should act in a certain way.

1.2. Negative and positive conflicts of jurisdiction arise in concrete cases (conflicts of adjudicative jurisdiction), while lack or concurrence of jurisdictions can be established in the abstract, through the analysis of the relevant normative systems.

However, if it is clear that settling a (negative or positive) conflict of jurisdiction supposes an actual situation, the prevention of such conflicts can be done, to a certain extent, in the abstract, by expanding the reach of the relevant law systems and / or imposing duties to prosecute certain offences (negative conflicts), or by reducing the overlap between those systems (positive conflicts).

\section{Negative conflicts}

2.1. As said, asserting that there is a negative conflict of jurisdiction has a normative value: someone should have, or exert, jurisdiction. Traditionally, the relevant point of view is that of the States connected to the facts: taking into account their legal systems and criminal policy programmes, it can be assumed that the lack of jurisdiction over a particular situation is a mistake, a lacuna. Therefore, a negative conflict of jurisdiction requires action by the States, either on an individual or collective basis, so as to amend their jurisdictional rules and avoid the undesired result, or the adoption of concrete measures to investigate, prosecute and try a case that falls under their jurisdiction.

If the EU has jurisdiction to prevent and settle negative conflicts of jurisdiction between Member States, this means that it has been conferred the power to qualify a given lack of jurisdiction by a plurality of States as a negative conflict of jurisdiction, according to some criterion. However, such criterion is yet to be determined: when is the EU entitled to decide that (some) Member States should have, or exert, jurisdiction over a situation?

2.2. Solving negative conflicts of jurisdiction is a specific criminal law problem and requires the EU to use the specific powers embodied in its own jurisdiction in criminal matters.

a) Before the entry into force of the Treaty of Lisbon, the limitation of EU legislative action to certain forms of criminality, laid down in article 31 (1) (e) TEU-N (organised 
crime, terrorism and illicit drug trafficking) ${ }^{20}$ concerned only the "approximation" (article 29 TEU-N) of "the constituent elements of criminal acts and penalties". Therefore, jurisdictional issues fell under the Union's general power to adopt "framework decisions for the purpose of approximation of the laws and regulations of the Member States" (article 34 (2) (b) TEU-N), limited only by the general requirement of consistency of EU legislation with the "objectives" and competences set forth in article 29 TEU-N.

Hence, the EU could adopt framework decisions aiming at avoiding (negative or positive) conflicts of jurisdiction in relation to any type of crime, as a means of furthering "common action on judicial cooperation in criminal matters" (article 29, $\S 2,2^{\text {nd }}$ ind., and article 31 (1) (d), of the TEU-N). ${ }^{21}$

However, it is doubtful whether the general competence to prevent negative conflicts of jurisdiction was consistent with the limits ratione materiae set in article 31 (1) (e) TEU-N: it made little sense that the EU could have a stand to impose on Member States duties to extend the applicability of their criminal law over offences that did not fall under its material jurisdiction. For instance: one fails to see why the EU should have the power to impose on Member States the duty to introduce universal jurisdiction, or the

20 Most authors upheld an "extensive" interpretation of article 31 (e) TEU-A, so that the Treaty of Amsterdam would not mean a step backwards in relation to the pre-existing "acquis communautaire" in criminal matters: see, e. g., Martin Böse, EU-Kommentar (hrsg. Jürgen Schwarze), 2000, Art. 31 EUV, mn. 10; Helmut Satzger, Internationales und Europäisches Strafrecht, 2005, § 8, mn. 43; Bernd Hecker, Europäisches Strafrecht, 2005, § 11, mn. 87 ff.; Kai Ambos, Internationales Strafrecht. Strafanwendungsrecht. Völkerstrafrecht. Europäisches Strafrecht, 2nd Ed., 2008, $\S 12$, mn. 9 ff. However, it is worth noting that the restriction of EU action to those three domains of criminality concerned exclusively the approximation of "the constituent elements of criminal acts and penalties" (not other dimensions of criminal law), and only the approximation effected through framework decisions (not through other instruments, like, say, conventions). Hence, the material limitation contained in article 31 (1) (e) would hardly constitute a regress in relation to the previous stage of European competences in criminal matters, where the possibility of approximating primary criminal law through autonomous, binding European instruments did not even exist. Whether or not a more ambitious solution could (and should) have been put into place in the Treaty of Amsterdam is obviously a different issue.

Therefore, it is submitted that EU organs have disrespected several times the material boundaries of EU jurisdiction by approving framework decisions to approximate primary criminal law in fields such as the environment, child pornography and, generally, all forms of nonorganised crime, save terrorism and illicit drug trafficking (in this sense, see Gert Vermeulen, "Where do we currently stand with harmonisation in Europe?", in André Klip / Harmen van der Wilt (eds.), Harmonisation and Harmonising Measures in Criminal Law. Proceedings of the Colloquium, Amsterdam, 13-14 December 2001, 2002, p. 69 ff.; Pedro Caeiro, "A Decisão-quadro do Conselho, de 26 de Junho de 2001, e a relação entre a punição do branqueamento e o facto precedente: necessidade e oportunidade de uma reforma legislativa", in Liber Discipulorum para Jorge de Figueiredo Dias, Coimbra Editora, 2003, p. 1070 ff.; and Anabela Miranda Rodrigues, O Direito Penal Europeu Emergente, Coimbra Editora, 2008, p. 113). Those instruments are illegal, on the grounds of violation of the Treaty (lack of competence: article 35 (1) and (6) TEU-A), and the Conclusions of Tampere (which are many times invoked to support the extension of EU competence) are of no help to that effect, because they bear no formal juridical value: in detail, Pedro Caeiro (n. 5), p. $121 \mathrm{ff}$.

21 In detail, Pedro Caeiro (n. 5), p. 1071 ff.; Miguel Ângelo Lemos, O Défice Democrático na União Europeia e o Direito Penal, master's thesis, available at $<$ http://www.fd.uc.pt/ma/ doc1.pdf >; but see, in the opposite sense, Gert Vermeulen (n. 20), p. 69. 
protective principle, in relation to, say, non-organised corruption of national officials, so that any Member State would be able to prosecute and try corruption committed abroad.

Concerning crimes perpetrated against EU interests (not included in article 31 (1) (e) TEU-N), it might be argued that a negative conflict of jurisdiction could cause the violation of the principle of equivalent protection by the Member States somehow connected to the offences (those who should exert their jurisdiction), and the EU should therefore be entitled to prevent or settle such conflicts. Yet, it is not the negative conflict itself that hampers on equivalent and adequate protection, but rather the fact that each Member State involved is not acting as expected and, as a consequence, is violating its own duties, irrespective of whether it lacks jurisdiction over the case, or does not exert it, or does not consider such conduct as an offence.

Hence, before the entry into force of the Treaty of Lisbon, the possible dissociation of EU's competences on negative conflicts of jurisdiction from those regarding the approximation of substantive criminal law was hard to justify.

b) At this stage, it is necessary to differentiate between negative and positive conflicts of jurisdiction, because they are not two sides of the same coin: from the point of view of EU competences, they are fundamentally different.

The prevention of positive conflicts does not create a duty to punish and, arguably, does not even suppose a specific jurisdiction in criminal matters such as the one laid down in article 31 (1) (e) TEU-N (and, presently, in article 83 (1) and (2) TFEU). In that case, the EU is not exerting its own jurisdiction in criminal matters, but rather coordinating or rationalising existent jurisdictional claims of the Member States, with a view to safeguarding interests other than the simple prosecution of offenders. In other words, the interest in punishment and crime control is already protected by the Member States before or without EU's intervention, which means that the EU acts here in a completely different vest.

c) At first sight, the Treaty of Lisbon did not modify the legal framework introduced in Amsterdam: legislative measures on the prevention and settlement of conflicts of jurisdiction (article 82 (1) (b) TFEU) were explicitly kept separate from the establishment of "minimum rules concerning the definition of criminal offences and sanctions", and, thus, do not seem to be limited by the boundaries set in article 83 (1) (2) TFEU.

However, there is an important difference between the wording of article 31 (1) (e) TEU-N and article 83 (1) (2) TFEU that might allow for a more adequate construction of the regime, so as to accomodate the arguments against the dissociation of competences regarding, on the one hand, the prevention and settlement of negative conflicts and, on the other hand, the imposition of duties to criminalise. As a matter of fact, the former norm made a strict reference to "the constituent elements of criminal acts", that is to say, the content of the prohibition, while the latter refers, more generally, to the "definition of criminal offences". The truth is that any substantive criminal norm is incomplete and useless if it is not coupled with rules that provide for its applicability. Thus, it is submitted that EU legislative action concerning the prevention and settlement of negative conflicts of jurisdiction participates in the "definition of the criminal offences" at 
stake, and is subject, therefore, to the material ambit ${ }^{22}$ drawn in article 83 (1) (2) TFEU. ${ }^{23}$

2.3. This construction helps to clarify the reason why the EU holds a specific, legitimate competence to prevent and settle negative conflicts of jurisdiction that does not derive from the general principle of equivalent protection: concerning the areas of criminality referred to in article 83 (1) (2) TFEU, the Union has an autonomous, legitimate claim that those offences do not go unpunished, irrespective of whether impunity results from lack of appropriate primary norms or rules of applicability, or lack of adequate action. As a result, if a plurality of Member States bearing a connection to the facts lack or do not exert jurisdiction over those offences, the EU might as well endeavour to solve the problem at a legislative or executive level (through Eurojust).

Finally, it should be noted that, in doing so, the EU may face a dilemma, since preventing negative conflicts of jurisdiction might increase the risk of creating positive conflicts, which would run counter article 82 (1) (b) TFEU. In order to avoid that risk, the EU should change the approach pursued in the last decade and refrain from imposing on Member States the duty to adopt multiple rules of applicability (in general, territoriality and active nationality will suffice to avoid negative conflicts), as well as from creating new rules and generalising others that are unknown to many Member States (e. $\mathrm{g} .$, the domicile of the perpetrator)

\section{Positive conflicts}

3.1. In principle, concurrence of jurisdictions (taken in the abstract or even in the face of an actual situation) does not give rise to positive conflicts of jurisdiction. Each jurisdiction has the autonomous power to adjudicate the case, paying no consideration whatsoever to the claims of the others, as long as it complies with its international duties: the holders do not have to compete to prevail over each other, as if there was space for one decision (and the application of one law) only. ${ }^{24}$

However, concurrence of jurisdictions turns into a conflict when a plurality of States claim jurisdiction over a given case and, from a certain point of view, it would be undesirable or illegitimate to have multiple decisions adjudicating that case. That point of

22 The fact that Eurojust is endowed with the power to ask the competent authorities of the Member States "to undertake an investigation or prosecution of specific acts" that might fall outside the categories of offences indicated in article 83 (1) (2) TFEU (articles 6, 1, a), (i), and 7, 1, a), (i), of the Council Decision 2002/187/JHA setting up Eurojust with a view to reinforcing the fight against serious crime, as amended by Council Decision 2009/426/JHA

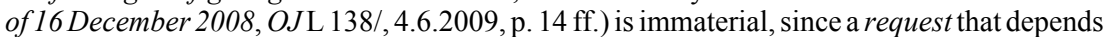
on the acceptance of the addressed Member State does not qualify as a jurisdictional power proper.

23 The "minimum rules" requirement is not problematic, because the prevention of negative conflicts implies, by definition, the setting of minimum jurisdiction.

24 This is altogether different from the conflict of laws in private law, for the settlement of which it is necessary to choose one of the competing laws by applying abstract and previously set criteria that do not take into consideration the material solutions provided by law A or B, but rather state that, in the abstract, a situation pertaining to a given category shall be regulated by law A or B. 
view is external to the jurisdictions involved, ${ }^{25}$ supposing an inter-state (sc., general or particular international law) or a trans-state (sc., international or transnational organisations) normative context, and springs, inter alia, from the protection of individual freedoms and the proper administration of justice. The former includes avoiding double punishment, or even double jeopardy, for the same acts; the second intends to avoid contradictory decisions and waste of time and resources.

All those purposes converge to the conclusion that, as a principle, the case should be dealt with by one single jurisdiction, from the earliest possible moment. Nonetheless, which of the conflicting jurisdictions should be chosen is yet to be determined and some criteria will be needed, with a view to allocate jurisdiction to the best possible forum. This should be a purely formal judgment, where considerations of material justice or effectiveness of adjudication do not take place, because no autonomous, unbiased standards are available at a trans-state level, except for the "minimum rules" explicitly set by European acts. Consequently, one cannot take into account topoi such as the more or less punitive approach adopted by the conflicting jurisdictions, the probability of conviction / acquittal, whether or not there is a duty to prosecute (legality / opportunity), whether or not prosecution is time-barred, the volume of evidence available, etc. The best possible forum is the State where the effects of the alleged offence were more detrimental to public trust in the validity of the violated norms and, consequently, where public response is more intensely needed. This definition equals, in most cases, the territorial State (provided, of course, that its law punishes the relevant conduct as a criminal offence). ${ }^{26}$

Once the best possible forum is determined, and because the actual exercise of multiple jurisdictions is, in the submitted definition, inconvenient or illegitimate, it can be

25 Indeed, domestic systems can also prevent conflicts of jurisdiction themselves (e. g., by shunning negative conflicts through surrogate jurisdiction ["stellvertretende Strafrechtspflege"], or positive conflicts through subjection of extraterritorial jurisdiction to a clause of subsidiarity), but that does not change the external nature of the relevant perspective.

26 Arguably, the definition of "the best possible forum" needs further elaboration. However, it does not follow that its concretisation must be encapsulated in positive binding criteria, even in the flexible formula proposed by Otto Lagodny, Empfiehlt es sich, eine europäische Gerichtskompetenz für Strafgewaltskonflikte vorzusehen? Gutachten im Auftrag des Bundesminsteriums der Justiz, Berlin, March 2001, p. 104 ff., where the "quality of the jurisdiction" would be assessed through a combination of multiple, non-hierarchised factors (a jurisdiction would be as more adequate as it is the territorial State, or the State where the perpetrator resides, etc.), according to the principle of "practical concordance" (K. Hesse). Rather, the definition seems determinate enough to allow for direct application by the competent authorities, especially if the judiciary is involved. In any case, some of the mentioned factors are certainly most relevant for assessing in which jurisdiction the alleged offence had the most detrimental effects (e. g., the territory where the most characteristic elements of the offence ["Schwerpunkt des charakteristischen Unrechts"] occurred). 
said that multiple prosecutions / trials are unnecessary. Only then can the univocity of criminal justice and the efficiency of resources be assumed as common goals. ${ }^{27}$

3.2. The prevention and settlement of positive conflicts in the specific field of European integration should follow a self-referential perspective: the conception of Europe as a common area of justice, built on the normative assumption ${ }^{28}$ of mutual trust between Member States, which gives rise to mutual recognition of foreign judicial decisions. ${ }^{29}$ The basic idea to be drawn from such perspective is that there is a prima facie equivalence between all Member States for the prosecution and adjudication of the case. ${ }^{30}$ Against that background, actual concurrence of jurisdictions over a case is perceived as a conflict that should be prevented or settled.

It is worth noting that the equivalence of jurisdictions is a mere pre-condition that allows for solving the conflict by allocating jurisdiction to the best possible forum. Yet, despite the enactment of FD CJur and the competences of Eurojust in this field, ${ }^{31}$ there are no binding mechanisms that provide for such allocation. Moreover, both approaches are based on consensus between the competent authorities, and they suggest that conflicts of jurisdiction should be settled in favour of the best prosecution possible, which is indeed a biased way of facing the issue. ${ }^{32}$

In the context of a project of common justice, where ne bis in idem is already implemented, aiming at the settlement of conflicts of adjudicative jurisdiction is more than justified. It can be done through consultation between the interested States, with the participation of Eurojust (if necessary), possibly coupled with a binding decision by the

27 It is submitted that circumventing double punishment (and perhaps double jeopardy) can be seen as a common goal irrespective of whether or not the final decision has been taken in the best possible forum - and that is the reason why the European prohibition of ne bis in idem has preceded any attempt to organise the allocation of jurisdiction in criminal matters. In the absence of such organisation, it is probably more adequate to have ne bis in idem in force rather than not, but that is not necessarily the best possible solution: see infra, 3.4.

28 See also André Klip, "European integration and harmonisation and criminal law", in D. Curtin / J. Smits / A. Klip / J. McCahery, European Integration and Law, Intersentia, 2006, p. 137; and Valsamis Mitsilegas, EU Criminal Law, Hart Pub., 2009, p. 148.

29 Actually, mutual recognition is more dependent on knowledge (of the re-cognisable Other and his law system) and will (to treat his action as One self's) than trust, which, as an open-ended concept, consists solely of the assumption that the other State's practice conforms with the requirements of its own, previously recognised, legal system.

30 See Framework Decision 2009/948/JHA, of 30 November 2009, on prevention and settlement of conflicts of exercise of jurisdiction in criminal proceedings, OJ L 328, 15.12.2009, p. $42 \mathrm{ff}$ (FD CJur), $12^{\text {th }}$ recital of the Preamble: “(...) the principle of mandatory prosecution, governing the law of procedure in several Member States, should be understood and applied in a way that it is deemed to be fulfilled when any Member State ensures the criminal prosecution of a particular criminal offence".

31 Articles 6 (1) (a) (ii) and 7 (1) (a) (ii) of Council Decision 2002/187/JHA setting up Eurojust with a view to reinforcing the fight against serious crime, as amended by Council Decision 2009/426/JHA of 16 December 2008, OJ L 138/, 4.6.2009, p. $14 \mathrm{ff}$.

32 According to the Preamble of FD CJur, Member States should "consider legislation on conflicts of jurisdiction, with a view to increasing the efficiency of prosecutions while guaranteeing the proper administration of justice" ( $2^{\text {nd }}$ recital, emphasis added), and "specific attention should be paid to the issue of gathering the evidence which can be influenced by the parallel proceedings being conducted" (4th recital). See also Valsamis Mitsilegas (n. 28), p. 156. 
Court if consensus cannot be reached, or if the alleged perpetrator (suspect / accused / defendant) does not agree with the decision taken by the authorities involved. ${ }^{33}$

3.3. Another way of avoiding positive conflicts of jurisdiction is to prevent them by reducing the ambit of applicability of domestic criminal law systems and, consequently, the overlap between them.

However, establishing rigid abstract rules (e. g., limiting domestic jurisdiction to territorial offences) could lead to overlooking other interests that, in a concrete situation, make it advisable to try the case in a different jurisdiction; additionally, it would not solve conflicts rising from territorial dispersion of criminal conduct.

If a reliable and swift mechanism of settling positive conflicts of jurisdiction since an early stage is put into place, preventing them does not seem very pressing. It seems enough, at this level, that EU law does not continue to multiply mandatory and optional rules of applicability, as it has done in the past few years.

3.4. The approach followed by the FD CJur (conflicts should be settled in order to avoid a possible infringement of ne bis in idem $)^{34}$ is rather equivocal, because the respect for ne bis in idem is an autonomous, self-standing duty, already binding upon Member States, and consequently, in the current legal framework, multiple jurisdiction can never lead to a legitimate exclusion of that bar. In other words, conflicts are to be solved or prevented not to ensure that respect for ne bis in idem follows, but rather to bring existing ne bis in idem into line with a notion of common justice. When that happens, ne bis in idem will be envisaged as a natural consequence of having the case adjudicated in the best possible forum, in the context of the European area of common justice: "your justice is my justice". 35

Nevertheless, in the absence of a mechanism to allocate jurisdiction, the rule ne bis in idem set in article 54 of the Convention Implementing the Schengen Agreement (CISA) creates an awkward situation, where the first final decision pre-empts possible decisions from other jurisdictions (not quite "first come, first served", 36 but rather "only the first one will be served", or, more colloquially, "the early bird catches the (single) worm").

33 See Otto Lagodny (n. 26), p. $127 \mathrm{ff}$.

34 See $3^{\text {rd }}$ and $12^{\text {th }}$ recitals, as well as article 1 (2) (a) FD CJur.

35 Common justice does not mean, to this effect, that the State prosecuting and trying the case is supposed to do justice as a functional representative of all the States with jurisdiction over the case, or that the content of the decision should be satisfactory to all of them. As mentioned, mutual recognition allows for the equivalence between Member States as a formal pre-condition for choosing the best possible forum (every State is eligible) and, in that framework, it cannot refer to the material justice of foreign decisions, nor depend on their being palatable by the recognising jurisdiction. Underlying mutual recognition is precisely the idea that playing by common formal rules bears an inherent value that pays for possible detriment to the material justice of the case as seen by the recognising jurisdiction.

In the opposite sense, making mutual recognition depend on the awarding of sufficient protection to the relevant legal interest by the first decision in the context of ne bis in idem, see Martin Böse, "Der Grundsatz »ne bis in idem « in der Europäischen Union", GA 2003, p. 760, and Kai Ambos (n. 20), p. 488.

36 Commission Staff Working Document Annex to the Green Paper On Conflicts of Jurisdiction and the Principle of ne bis in idem in Criminal Proceedings, Brussels, 23.12.2005, SEC(2005) $1767\{\mathrm{COM}(2005) 696$ final $\}$, p. 5. 
In fact, ne bis in idem is not a criterion for preventing or settling conflicts of jurisdiction, but a bar that prevents other States' jurisdiction. ${ }^{37}$ It certainly is an effective impediment against double punishment for the same acts, but it does not ensure that the best possible forum is chosen.

Moreover, the present regulation of ne bis in idem can cause further dysfunction: conflicting jurisdictions might get into a real competition, because each one of them might as well want to make sure that the others, relying on a less important (or so perceived) contact with the situation, will not "steal" the case and prevent it from having (its) justice done.

\section{$I V$. Beyond negative and positive conflicts: jurisdiction in neutral ("zero-sum") situations}

1. There is still a whole entirely different field for the prevention of conflicts of jurisdiction, and the word "jurisdiction" should now be understood in its objective sense (as Gebiet).

It can happen that the lex loci does not consider the act as a crime, ${ }^{38}$ but an applicable law of another Member State does. ${ }^{39}$ This might not be very common, but it is possible, especially if we bear in mind that harmonisation of substantive criminal law is subject to the so-called minimum rules pattern, where the States are left the discretion to create broader incriminations. Such ever unfinished harmonisation, coupled with the circumstance that many framework decisions impose upon Member States the duty to implement rules of extraterritorial jurisdiction that do not embody dual criminality, make the risk of disparate applicable laws even more plausible.

2. Hence, there is also a conflict of jurisdiction, it is submitted, when an individual might be subject to two contradictory laws. Conflicts of jurisdiction should not be seen only in the perspective of the application of the law to an act that has already been committed, but also in the perspective of determining which law should be obeyed by individuals when they act; or in other words, law should not be seen only as norms that sanction forbidden conduct, but also as norms that command individual behaviour.

In those cases, there are strong arguments for the limitation of extraterritorial jurisdiction by requiring mandatory double criminality for acts committed within the EU, except where international law dispenses it (rules of protection and universality, or conventional clauses).

From a liberal point of view, every State should ensure that no-one acting in its territory gets punished except where its own law or international law command otherwise. Each State has the right, and possibly the duty, to guarantee not only individual freedom

37 Contrary to what one might believe, inter-jurisdictional ne bis in idem is not that modern. In fact, it regulated, for a number of centuries, the parallel jurisdictions of the States and the Catholic Church regarding the so-called mixti fori offences: first decision was the valid one and, as the other jurisdiction got prevented, a true competition sometimes emerged: see Pedro Caeiro (n. 5), p. $149 \mathrm{ff}$.

38 "Crime" means here an unlawful act punished by penal law (tatbestandsmäßige, strafrechtswidrige Tat).

39 E. g., by virtue of nationality, residence, or unilateral universality. 
to act, but also individual freedom to decide to act abiding by the local law. Thus, unless otherwise permitted by international law, it is unacceptable that another State claims extraterritorial jurisdiction over conduct that is not prohibited under the lex loci. ${ }^{40} \mathrm{Such}$ a claim, namely in the case of active or passive nationality, is an unlawful intervention forbidden by general international law.

The preceding considerations apply generally to the international context, ${ }^{41}$ but bear a particular strength in the EU. In the context of integrated legal pluralism, mutual recognition should extend also to foreign law under certain conditions, one of them being the circumstance that the conduct at stake is not a criminal offence under the lex loci. As a matter of fact, a similar reasoning seems to underlie article 4 (7) (a) of the Framework Decision on the European arrest warrant, ${ }^{42}$ which allows for refusal of surrender on the mere grounds that the acts occurred in the territory of the executing Member State, even if it is a listed offence; and article 55 (1) (a) CISA, which allows Member States to declare that they will not be bound by article 54 in the case where the acts to which the foreign judgment relates took place, in whole or in part, in their territory.

3. In the context created by the implementation of European ne bis in idem, the absence of mandatory double criminality for the exercise of extraterritorial jurisdiction may cause very awkward situations, as in the following example.

Portugal has transposed the Framework Decision on sexual exploitation of children and child pornography ${ }^{43}$ in a most scrupulous way, and, since 2007, the Portuguese Penal Code (PPC) punishes he who produces, distributes, buys or possesses "images of a real person appearing to be a child, or realistic images of a non-existent child involved in sexually explicit conduct". 44

Moreover, this offence is now subject by Portuguese law to (unilateral and, thus, illegitimate $v i s$ - $a$-vis international law $)^{45}$ universal jurisdiction, the sole connection with Portugal being the perpetrator's presence in the country and the impossibility of extradition or surrender. ${ }^{46}$

Let us recall that article 3 (2) FD ChPorn allows Member States to exclude such conduct, under certain circumstances, from "criminal liability" - or, in the more accurate German version, from the prohibiting norm itself. ${ }^{47}$

40 The same concern for respect for the lex loci has led André Klip to argue in favour of limiting the scope of domestic criminal law to territorial facts (for crimes committed within the EU), coupled with a body of true, unified European criminal law, while, at the same time, excluding double criminality from judicial cooperation: see André Klip, "The Constitution for Europe and criminal law: a step not far enough", MJECL 12-2 (2005), p. $119 \mathrm{ff}$.

41 See Kai Ambos (n. 20), p. 36 f., mn. 40 f., p. 44, mn. 57.

42 Framework Decision of 13 June 2002 on the European arrest warrant and the surrender procedures between Member States (2002/584/JHA), OJ L 190, 18.7.2002, p. $1 \mathrm{ff}$.

43 Framework Decision 2004/68/JHA, of 22 December 2003, on combating the sexual exploi-

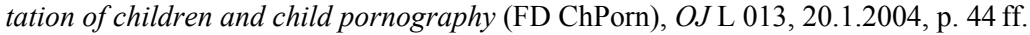

44 Article 1, b), ii) and iii), together with article 3 FD (= article $\left.176^{\circ}, \mathrm{n}^{\circ} 1, \mathrm{~d}\right)$, and $\mathrm{n}^{\circ} 3$ PPC).

45 Pointing out several instances of illegitimate universal jurisdiction, see Kai Ambos (n. 20), p. $52 \mathrm{ff}$.

46 Article $\left.5^{\circ}, n^{\circ} 1, c\right)$, PPC.

47 "Ein Mitgliedstaat kann festlegen, dass die nachstehenden Handlungen im Zusammenhang mit Kinderpornografie keinen Straftatbestand erfuellen" (emphasis added). 
This means that, if the perpetrator is found in Portugal, Portuguese authorities have the duty to prosecute, try and punish a national or foreign citizen who has lawfully produced, distributed, etc., such material in a Member State that has (legitimately - and wisely) chosen not to consider those acts as a criminal offence.

However, there is an exception to Portuguese (adjudicative) jurisdiction: if that Member State has prosecuted the case - because it was doubtful, for instance, whether a real child was used as a model, in which case the act would be a crime under the lexi loci - and acquitted the defendant on the grounds that there were no real children involved, then the jurisdiction of Portuguese courts would be prevented by ne bis in idem (decision on the merits regarding the same acts, in the light of Van Esbroeck). ${ }^{48}$

The conclusion is that, according to the current European legal framework, Member States can claim extraterritorial jurisdiction over conduct that is not an offence in the Member State where it occurred, unless the latter has certified so by the means of a prior acquittal (or analogous final decision) of the "offender".

It is submitted that non-liability, in those cases, should not depend on immaterial circumstances such as the actual existence of an acquittal and the precedence of the decision over other jurisdictions: it should rather be ensured by prohibiting wild extraterritorial jurisdiction in the area of common justice.

48 Case C-436/04, Van Esbroeck, 9.03.2006, ECR (2006) I-2333, para. 25 ff. A different solution might be upheld by the authors who propound a more normative approach towards ne bis in idem: The bar would not cover acts that have been adjudicated by the first jurisdiction in a way that does not award sufficient protection to the relevant legal interests, in the eyes of the second, unsatisfied jurisdiction (see supra, n. 35). Arguably, there is merit in this contention as long as the second jurisdiction is the territorial State. Yet, in the reverse case, it is not clear why a State should have the right to exert extraterritorial jurisdiction over conduct for which the territorial State has acquitted (or decided not to prosecute) the defendant (or the suspect) on the basis that those acts do not constitute a crime before its own law. 